Área Abierta. Revista de comunicación

audiovisual y publicitaria

ISSN: 2530-7592

\title{
Génesis y formalización del toque religioso en los documentales agrarios del Marqués de Villa-Alcázar
}

\author{
Pedro Poyato Sánchez ${ }^{1}$
}

Recibido: 15 de febrero de 2016 / Aceptado: 24 de abril de 2016

Resumen. Una de las características de la obra cinematográfica del Marqués de Villa-Alcázar es la presencia en ella de lo que el propio Marqués llamaba "toque espiritual o religioso". El presente trabajo se interesa por el análisis de ese toque desde su escritura en el guión hasta, pasado el preceptivo proceso de censura, su formalización en el filme, con el fin de constatar su recurrencia en unas cuantas producciones marquesianas pertenecientes a épocas distintas del régimen franquista.

Palabras clave: cine; marqués de Villa-Alcázar; toque religioso; nacionalcatolicismo; censura

[en] Genesis and Formalization of the Religious Hue in Marqués de VillaAlcázar's Agricultural Documentaries

Abstract. One of the characteristics in Marqués de Villa-Alcázar's film work is the presence of what he called the 'religious or spiritual hue'. This paper focuses on the analysis of that hue from the script writing up to - after the mandatory censorship process - its formalization in the film, with the aim of verifying its recurrence in several of his productions from different stages of Francoism.

Keywords: Film; Marqués de Villa-Alcázar; Religious Hue; National Catholicism; Censorship

Sumario. 1. Introducción. 2. Línea de filiación y contexto en el que surge el documental marquesiano. 3. Trigo en España: trigo, pan y cuerpo de Nuestro Salvador. 4. Oro líquido: el aceite de oliva como aceite litúrgico. 5. Dátiles y palmas: la palma blanca y la procesión de Ramos. 6. A modo de coda. 7. Bibliografía

Cómo citar: Poyato Sánchez, P. (2017) Génesis y formalización del toque religioso en los documentales agrarios del Marqués de Villa-Alcázar, en Área Abierta. Revista de comunicación audiovisual y publicitaria 17 (2), 213-227. http://dx.doi.org/10.5209/ARAB.51895

\section{Introducción}

Es mi deseo que todas las películas educativas que haga este Ministerio bajo mi dirección lleven en ellas un toque espiritual o religioso ${ }^{2}$.

1 Universidad de Córdoba (España)

E-mail: aa1posap@uco.es

2 Carta enviada por el Marqués de Villa-Alcázar el verano de 1942 a la Censura Eclesiástica, Departamento de 
La formulación de este deseo enunciado por el propio Marqués de Villa-Alcázar, autor de una vasta obra documental realizada a lo largo de cuatro décadas (19341966), producida por el Ministerio de Agricultura y destinada a la transferencia de conocimientos agrícolas, forestales y ganaderos, acabaría por convertirse en realidad en todos aquellos casos en los que la película en cuestión lo permitiera, si no de modo directo, lo cual no resultaba nada fácil por tratarse de documentales agropecuarios, sí indirectamente, por ejemplo al hilo de determinadas aplicaciones de los elementos protagónicos del filme como, por caso, el trigo, el aceite o las palmas. Y así puede en efecto constatarse a lo largo de la producción cinematográfica marquesiana, desde los cuarenta, años de autarquía vinculados al franquismo más duro, hasta los sesenta, años del famoso desarrollismo franquista. El objetivo del presente trabajo es el estudio, basado en una metodología de análisis que toma en consideración el contexto de producción de la obra, de ese toque o apunte religioso, desde su trazado en la escritura del guión hasta su formalización en el filme - procesos, ambos, que, como era preceptivo, habían de someterse al beneplácito de la censura-, en algunos de los documentales más representativos del Marqués de Villa-Alcázar, desde Trigo en España (1943) hasta Oro líquido (1965) y pasando por Dátiles y palmas (1947), con el fin de constatar su recurrencia. Pero comencemos haciendo antes un poco de historia referida a la situación del documental de tema agrario en la España donde aflora la obra marquesiana.

\section{Línea de filiación y contexto en el que surge el documental marquesiano}

Las películas del Marqués de Villa-Alcázar se inscriben en una tradición de cine documental que, remontándose al pionero del cine español Fructuoso Gelabert; a Enrique Blanco, a quien se debe La historia del toro de lidia (1911), filmada en la ganadería extremeña de Olea; y a Antonio de Padua Tramullas, realizador de numerosos documentales agrarios como Plaga de langosta (1912), Valle de Ordesa (1912) o Fábrica de galletas Patria (1913), encontró en el ingeniero agrónomo Leandro Navarro el primer nombre importante. La patología vegetal fue la principal temática de los documentales de Navarro, a los que él solía añadir cuadros de mitología relacionados con el mundo rural: Fumigación de los olivos por medio de gas cianhídrico (1912-1914), Estudio de una plaga de langosta (1915-1917), Las uvas de embarque en Almería. Algo de mitología. Baco (1923) son buena muestra de esta obra documental en la que destaca su carácter de verdadera investigación sobre filopatología. Otro nombre importante es Pascual Carrión, también ingeniero agrónomo, quien realizó documentales, en este caso de divulgación, sobre ganado lanar, cultivo de cereales, los viñedos de Jerez o los palmerales de Elche, entre otros temas. Si los documentales de Navarro servían a la investigación, como antes decíamos, estos de Carrión eran considerados como herramienta auxiliar del catedrático, que encontraba en ellos un poderoso medio ilustrador de sus explicaciones, así como un vehículo de enseñanza para el labriego, quien, "merced al trabajo del objetivo cinematográfico, comprende de manera clara y sencilla cosas

Cinematografía, Velázquez, 59, Madrid. En Archivo General de la Administración, Alcalá de Henares, caja: 36/03204. Exp. 4399. 
que de otro modo tardarían en quedar grabadas en su mente"3. Se incide así en cómo se trataba en estos casos de películas instructivas sobre la mejora de la agricultura y la ganadería.

En esta misma línea de filiación del documental agropecuario en España se inscriben también el crítico cinematográfico Fernando G. Matilla y el biólogo Carlos Velo, quienes en 1934 realizaron La ciudad y el campo, un encargo de la Dirección General de Ganadería que abundaba en la importancia de la producción campesina organizada en sistemas cooperativos. Pero lo llamativo del filme es ahora su vinculación con La línea general (Serguei M. Eisenstein, 1929), sostenida a partir de un diálogo estético que afloraría igualmente, si bien en este caso con otros referentes cinematográficos como Nanouk el esquimal (Robert Flaherty, 1922), en la siguiente película, Almadrabas (1934), producida por el Consorcio Nacional Almadrabero, organismo dependiente del Ministerio de Marina. El propio Matilla decía en el número de julio de 1935 de la revista $L a$ Cruz, a propósito de este filme:

Nosotros no tomamos al empezar un documental el álbum de fotografías de la ciudad. No queremos hacer un desfile de fotos sin contenido, ya que nuestro lema es buscar el alma de las piedras, sus secretos: vamos en busca de un contenido tradicional, artístico o histórico ${ }^{4}$.

Estas palabras vienen a subrayar el calado de la dimensión histórica y estética de estos filmes. Pues bien, esta es la línea general en la que se inscribe el documental rural del Marqués de Villa-Alcázar, una vasta obra en la que, a diferencia de las anteriores, destaca, más que el carácter de investigación, de divulgación, o de filiación estética de las imágenes, que también, una carga ideológica acorde con el nacional-catolicismo preconizado por el franquismo. Carga que, en los casos que van a ocuparnos, anida, como antes señalábamos, en el llamado toque espiritual o religioso. Es este un rasgo que convierte al documental marquesiano en singular por cuanto lo diferencia no ya de la tradición, como acabamos de ver, sino también de las corrientes documentalistas de su contemporaneidad, entre las que cabe destacar, por ejemplo, la practicada por Guillermo Zúñiga, quien, en la línea de Leandro Navarro, apostó por un tipo de documental agrario de investigación científica rigurosa, si bien en este caso las imágenes trabajan, además de los vínculos entre el cine y la ciencia, los del cine y las artes. Interesado sobre todo por las abejas, Zúñiga realizó varios documentales en los que se exponen determinadas acciones sociales de las abejas como un relato antropomórfico que patentiza las relaciones de la ciencia con la arquitectura. En otro orden de cosas, Zúñiga, adelantándose al Marqués, que más tarde retomaría algunas de estas técnicas, destacó por sus progresos en el uso de la macrofotografía, por caso en Parásitos de las plantas (1965), así como por la utilización de nuevas tecnologías en escenas submarinas, como sucede por ejemplo en El mejillón de Galicia (1970).

Otros contemporáneos del Marqués fueron Manuel Hernánez Sanjuán, quien, a través de su productora Hermic Films, se convirtió, además de en portavoz cinematográfico oficial de las reivindicaciones colonialistas franquistas, en realizador, durante los años cuarenta y cincuenta, de una serie de películas como,

3 Miralles, A. (1933). "El cinema en la agricultura", $A B C$, (31 de marzo de 1933: 14).

4 Camarero (2014: 23). 
entre otras, Tierra de espigas (1945), interesada por mostrar el cultivo del cereal y la fabricación de pan; Los pobladores del mar (1947), un díptico que versa sobre la descripción de la fauna marina invertebrada y vertebrada, respectivamente; y Costas del Sur (1956) sobre la pesca del atún con el arte de la almadraba. Se trata de documentales meramente descriptivos con imágenes vinculadas, en el caso de la última citada, al arte cinematográfico de Carlos Velo (Almadrabas, 1934) o del mismo Roberto Rossellini (Stromboli, 1950). José Neches Nicolás, por su parte, comenzó trabajando para el Ministerio de Agricultura en dos filmes de los años cuarenta, Cortijo andaluz (1945), donde se explican las estancias de un cortijo y las labores que en él se desarrollan, y Reses bravas (1945), un documental sobre la vida del toro de lidia, hasta que, mediada la década de los cincuenta, se encargó del Departamento Cinematográfico del Servicio de Extensión Agraria, desarrollando entonces una labor que comprende más de cuarenta documentales caracterizados algunos de ellos por su formato de conferencia con ilustraciones, mientras que otros introducen en su interior la figura de un personaje que va mostrando, a través de sus andanzas, una comarca rural y las actividades que llevan a cabo los vecinos para el desarrollo económico de la zona.

Pero al igual que sucedía en los documentales previos a la obra marquesiana, tampoco estos otros trabajan la componente ideológica que interesaba al Marqués, ni siquiera aquellos que declinan las mismas temáticas, así sea el caso de los viñedos de Jerez, o de los palmerales de Elche (Leandro Navarro), o del trigo y la fabricación del pan, como en Tierra de espigas, cuyas imágenes para nada aluden, como Trigo en España, a la religión o a la patria en los términos de la película del Marqués de VillaAlcázar, sino que se vuelcan exclusivamente en la descripción ilustrada del cultivo y la aplicación del cereal. Todo ello convierte a los documentales agropecuarios del Marqués en una obra sin par, atravesada por una fuerte componente ideológica que se forja, como es el caso de los títulos barajados en este trabajo, a partir de la introducción del apunte o toque religioso.

\section{Trigo en España: trigo, pan y cuerpo de Nuestro Salvador}

Este documental arranca con un resumen de las distintas tareas a las que se somete el trigo, entre ellas las que tienen lugar en la era. Sobre imágenes de las espigas y del tratamiento posterior de estas, la voz over del narrador especifica sin ambages cuál es el objetivo de Trigo en España: hacernos independientes a los españoles, no depender de los países extranjeros, autoabastecernos, tal era la utopía predicada por el franquismo en los años de autarquía. Además de a la fabricación del pan, el filme alude al proceso de hibridación en el trigo. Y no faltan tampoco referencias a las distintas labores de la siega, así el corte con el haz de las espigas, la recolección de las gavillas, el transporte en los carros, la trilla y el aventamiento de la mies, en unas imágenes a las que el cine había sido ya sensible, el soviético, sobre todo, pero también el español en películas como Nobleza baturra (Florián Rey, 1935), cuyo

5 Para una información acerca de lo que esta pretensión del documental suponía, consultar: Marqués de VillaAlcázar. "Cinematografía agrícola, forestal y ganadera", en VV.AA. (1994). Conferencias pronunciadas en la emisión Radio Agrícola. Madrid: Ministerio de Agricultura. (1994: 385). 
arranque ha sido sin duda referente iconográfico de los segmentos anteriores ${ }^{6}$. Pero lo que a este trabajo interesa es el toque religioso con el que finaliza el documental. A las palabras del narrador: "Y el cultivador que produce trigo, hace labor patriótica, ayuda a sus hermanos y tiene la gloria de producir trigo; trigo..." - instante en el que comienza a sonar música religiosa - “... que es de todo cuanto en el universo existe, lo único que se puede convertir en el propio cuerpo de nuestro Salvador" acompañan imágenes de la custodia con la Sagrada Forma en manos del sacerdote cerrando el segmento. Así pues, la religiosidad, emanada tanto de la música como de la palabra que refiere la transubstanciación del pan en cuerpo del Salvador, y el patriotismo del cultivador de trigo, por cuanto contribuye a conseguir la independencia de los españoles reivindicada al principio, ponen punto final a Trigo en España.

Numerosos autores han llamado la atención acerca de cómo los dos pilares básicos de la ideología del nacionalcatolicismo eran precisamente la religiosidad y el patriotismo, binomio de valores que creó una fuerte interdependencia entre ambos. En este sentido, José Ángel Ascunce ha señalado que "españolidad y catolicidad marcaban el ritmo ideológico del pensamiento franquista"7. Y Alfonso Botti, por su parte, ha apuntado que fue plena la identificación entre catolicismo y España en todos los modos posibles, en tanto que "unidad política y unidad católica, razones de Estado y de la Iglesia han coincidido y deben volver a hacerlo" . Fue así cómo se creó un cuerpo de doctrina y de valores en el que el patriotismo y la religiosidad quedaban fusionados en un todo único e indivisible, como bien explicita el filme en el segmento analizado. Tal es la importancia discursiva de este apunte religioso y del que, merced a la documentación de archivo encontrada, se puede hacer un seguimiento desde que fuera redactado en el guión hasta su plasmación final en el documental; estudio que no solo va a iluminar la génesis del apunte en cuestión, sino que también, y sobre todo, va a contribuir a caracterizar y fijar algunas de las claves sobre las que se construye la forma cinematográfica marquesiana. Atendamos, pues, a esa documentación de archivo. En el expediente de guión presentado al comité de censura ${ }^{9}$ se hace constar muy someramente el argumento del filme:

En tiempos normales, produce España el 95\% del trigo que consume. Un pequeño esfuerzo, y perfeccionar métodos de cultivo es lo único que hace falta para conseguir la autarquía. La película trata de inducir al mejor cultivo y a utilizar los servicios del Servicio Nacional del Trigo para conseguir, para cada terreno, la semilla más indicada y que dé más rendimiento ${ }^{10}$.

Mas nada se dice acerca de cómo este argumento va a ser desarrollado, y por tanto nada se apunta sobre el toque religioso que cierra el filme. Para acceder a

6 Poyato, P. (2013). "Pedagogía, estética e ideología en los primeros documentales del Marqués de Villa-Alcázar", en Gómez-Tarín, F. J.; Parejo, N. (coords.). Discursos y narraciones en el documental rural: el marqués de Villa-Alcázar, Tenerife, Universidad de La Laguna (2013: 48-49).

7 Ascunce, J. A. Sociología cultural del franquismo. Madrid: Biblioteca Nueva (2015: 113).

8 Botti, A. Cielo y dinero. El nacionalcatolicismo en España (1881-1975). Madrid: Alianza Editorial (1992: 75).

9 Para un acercamiento a los distintos procesos de censura a los que habían de someterse los filmes durante el franquismo, véase: Gubern, Román. La censura. Función política y ordenamiento jurídico bajo el franquismo (1936-1975). Barcelona: Península (1981).

10 Archivo General de la Administración, carpeta 36/04660 
tal información ha sido necesario acudir hasta una carta personal que el Marqués de Villa-Alcázar dirige a la Censura Eclesiástica donde, como si del guión técnico se tratara, detalla cómo tiene planeado el final del documental, tanto por lo que se refiere a la banda de imagen, como a la de sonido:

Imagen:

Escena de era. Aventando trigo en primer término. La cámara sigue una carga del bielo, quedando en el centro del fotograma el momento de separarse la paja del trigo / Por fundido, se transforma ese trigo en la Sagrada Forma, en lo más alto de la Elevación, siguiéndole la cámara en su descenso, y fundido a la palabra FIN.

Sonido:

... y el cultivador que produce trigo, hace labor patriótica, ayuda a sus hermanos y tiene la gloria de producir trigo / ¡trigo! que es, de todo cuanto en el universo existe, lo único que se puede transformar [palabra tachada y sobre ella, escrita con pluma, convertir] en el propio cuerpo de nuestro Salvador.

Antes de impresionar esa parte de la película deseo saber si la Censura encuentra algo que corregir o sugerir, con objeto de estar siempre dentro de la más perfecta ortodoxia ${ }^{11}$.

Así pues, en escrito aparte del expediente oficial presentado a la Dirección General de Cinematografía solicitando la aprobación para la realización de la película, el Marqués de Villa-Alcázar adelanta a la censura eclesiástica la escritura del toque religioso que tiene planeado introducir en el filme con el fin de someterla a su juicio previo $^{12}$. El 9 de julio de 1942 el Marqués de Villa-Alcázar recibe una carta del vicesecretario de Cámara y Gobierno del Obispado de Madrid-Alcalá en la que se le remite el nihil obstat al guión del documental; nihil obstat que, firmado y rubricado por Andrés de Lucas con fecha de 8 de julio de 1942, aparece también al pie de la carta personal anterior. Trigo en España podía, pues, ser ya filmada. Mas como era preceptivo una vez finalizada la realización, la película tenía que ser enviada de nuevo a la Censura para su aprobación definitiva con vistas a la exhibición. Y así, el 30 de octubre de 1943, el Marqués de Villa-Alcázar remite la película a la consideración de la Censura oficial con el fin de obtener ahora el visto bueno para su proyección en todos los cines de España ${ }^{13}$. Pero a la vez escribe una carta personal manuscrita

11 Archivo General de la Administración, carpeta 36/03204. Exp. 4399.

12 Llama la atención en este escrito la corrección que en él se advierte sustituyendo, al referirse a la relación del trigo con el cuerpo de Cristo, el verbo "transformar" por el verbo "convertir". Corrección oportuna si se tiene en cuenta que, como advierte el catecismo católico, no se trata aquí de una mera transformación, de un cambio de forma, sino de algo mucho más profundo como es un cambio de sustancia, esto es, de una transubstanciación, acepción que sí puede hacer en parte suya el vocablo "convertir".

13 En el expediente se indican algunas características del filme, así que es una película educativa sobre el trigo; que el argumento, guión, operador (en este caso al alimón con Pérez-Cubero), montaje, jefe de producción y director es el mismo Villa-Alcázar; que el sistema sonoro es de Laffon-Selgar; la música es clásica; que no hay decorados, ni vestuario, ni secretario de estudio, y finalmente que tampoco hay intérpretes, si bien esta indicación se hace notar tras tachar los nombres de Conchita López, Mary Ruiz y Pilar Santisteban, indicando que las mismas aparecen en un plano cada una. En el expediente se indica también que la producción empezó 
a Antonio Fraguas, quien solía presidir la Comisión de Nacional de Censura, en los siguientes términos:

Después del tropiezo que sufrió mi película "Jerez-Xérès-Sherry" (que me ha dado bastante guerra para arreglarla de acuerdo con lo que hablamos) le envío para censurar esta película sobre el trigo con verdadero pánico. Claro que la autoridad de la Censura de Vd. es la final y definitiva, pero por si el hecho de que el toque religioso que lleva al final ha sido puesto con toda la buena fe del mundo, y después de obtenida (en 1942) el Nihil Obstat de la Censura Eclesiástica, le hace ser a Vd. un poquillo más indulgente, le envío como comprobación el Nihil Obstat citado ${ }^{14}$.

Carta esta que, a raíz de lo sucedido con Jerez-Xérès-Sherry ${ }^{15}$, demuestra el auténtico pavor que el Marqués de Villa-Alcázar tenía a la Censura, y ello porque cualquier modificación sugerida o impuesta le suponía, además de sentirse agraviado por el régimen del que él se declaraba ferviente seguidor ${ }^{16}$, modificar la obra original, con todo lo que ello conllevaba, además, de trabajo y de costes económicos adicionales. Pero, a diferencia de Jerez-Xérès-Sherry, la Censura no puso en este caso objeción alguna al filme, que pudo ser por tanto proyectado tal cual había sido concebido y realizado. En efecto: en su reunión de 5 de noviembre de 1943, la Comisión Nacional de Censura, presidida por Antonio Fraguas, y actuando como secretario Manuel Andrés Zabala, procedió a la censura de Trigo en España siendo la película aprobada íntegramente y clasificada para menores de 16 años, especificándose por separado los informes particulares. Así, el Moral y Religioso tachaba la película de "muy interesante"; el Pedagógico y de Cultura lo hacía en los términos de "precioso documental en todos los aspectos: letra, fotogramas y canciones"; y el Técnico, Político y Educación Popular en los de "documental magníficamente realizado". De este modo Trigo en España no solo fue aprobada íntegramente, sino que las distintas comisiones, en contra de lo que era habitual, se pronunciaron vertiendo sobre ella encendidos elogios. Al día siguiente, 6 de noviembre, la Comisión de Censura comunica el acuerdo al Gerente del Ministerio de Agricultura, así como el pago de los derechos de Censura. Y en documento dirigido al Ministerio de Agricultura, con fecha de salida de 18 de noviembre de 1943, la Delegación Nacional de Cine y Teatro remite el certificado en el que se hace constar la autorización para que la película, autorizada para todos los públicos, pueda proyectarse en las salas del territorio nacional ${ }^{17}$.

el 27 de febrero de 1942, finalizando el 4 de septiembre de 1943, y siendo expedido el permiso de rodaje el 28 de mayo de 1943. Finalmente, por lo que se refiere a la sinopsis del argumento, se refleja que no hay argumento por tratarse de una película destinada a “animar a sembrar más trigo y a cultivarlo mejor”. En Archivo General de la Administración, carpeta 36/03204. Exp. 4399.

14 Archivo General de la Administración, carpeta 36/03204. Exp.4399.

15 Nada hemos encontrado acerca de lo que sucedió realmente con este filme, si bien suponemos que en este caso el asunto que motivó las desavenencias tuvo que ver con el modo de expresión de la parábola política —la educación de los españoles, introducida a propósito de la educación de los vinos de Jerez- que animaba el filme. Pero este asunto escapa a los límites de este trabajo.

16 Así consta en la documentación de su expediente personal. Archivos del Ministerio de Agricultura, Madrid: expediente personal del Marqués de Villa-Alcázar.

17 Datos tomados, todos ellos, del expediente del filme. Archivo General de la Administración, carpeta 36/03204. Exp. 4399. 
Viene esto a demostrar que si con la introducción en sus documentales del toque religioso, el Marqués de Villa-Alcázar buscaba, por un lado, la complacencia del régimen haciendo apología de dos de sus pilares ideológicos como eran la religiosidad y el patriotismo, por otro lado temía que la censura, dado lo delicado del asunto, y como ya había tenido ocasión de constatar a propósito de su filme anterior Jerez-XérèsSherry, pudiera modificar la obra acabada. Tal es el interesante pulso que el Marqués de Villa-Alcázar mantuvo con una Censura a la que, amparándose en sus relaciones e influencias, optaría por solicitar el visto bueno de sus películas por adelantado con el fin de asegurarse una no modificación posterior de las mismas por lo que se refiere al planteamiento de un apunte vinculado al contexto histórico-religioso-político de la época. Pues bien: idéntica dinámica va a presidir la inclusión de ese toque religioso final en una película realizada más de veinte años después, Oro líquido, tanto por lo que se refiere a la génesis del mismo como a los avatares sufridos hasta su impresión final en el celuloide. Nos ocupamos de ello en los epígrafes siguientes, prestando también atención, al hilo del análisis realizado, a determinados segmentos del filme, como por ejemplo el del arranque, dado su interés político-discursivo.

\section{Oro líquido: el aceite de oliva como aceite litúrgico}

Oro líquido cierra el ciclo de cuatro películas que, en el marco de su extensa obra documental, dirigió el Marqués de Villa-Alcázar sobre las temáticas del olivar. Dedicadas al olivo, desde su plantación hasta la recogida y envasado del fruto, algunas; al tratamiento de morturación de la aceituna en el molino, otras; Oro líquido incorpora los modernos tratamientos de la aceituna para la obtención del aceite y sus aplicaciones, motivo este que, como se verá, va a servir de apoyo en este caso para la introducción en el filme del apunte o toque religioso. Pero comencemos atendiendo, dada su importancia político-discursiva, como antes decíamos, al arranque y cierre del filme.

Oro líquido comienza con una serie de imágenes que, pintadas a modo de carteles como fondo de los títulos de crédito, se ordenan como sigue: botella horizontal vertiendo aceite sobre el escudo de España de la Segunda República, como así lo certifica su configuración a partir de las armas de Castilla, León, Aragón, Navarra y Granada, y que se presente flanqueado por las columnas de Hércules, sin coronas, basadas en tierra, y con una cinta entrelazándose en la que figura escrita la leyenda Plus Ultra; escudo que aparece de este modo casi borrado por el grasiento líquido que va cubriéndolo. En las imágenes siguientes aparece sucesivamente la operación de llenado de las botellas, en la fábrica, y un olivo cargado de aceitunas. Este orden, inverso por lo que a la cronología propia del proceso de extracción del aceite se refiere, posibilita que la imagen que abre el filme sea precisamente la del soterramiento del escudo constitucional de la Segunda República, algo nada baladí si tenemos en cuenta que en la cartela que cierra el filme el título "fin" aparece sobreimpresionado al escudo de la España franquista, el del águila de los Reyes Católicos, que incorpora el lema "Una Grande Libre" junto con otros motivos heráldicos que se añaden a los del escudo tradicional de España (armas de Castilla, León, Aragón, Navarra y Granada, y las Columnas de Hércules con la inscripción "Plus Ultra") como el yugo y las flechas, tomado también del escudo de los Reyes Católicos. Es así cómo la película se enmarca entre estos dos escudos interconectados entre sí por cuanto si el uno, 
el constitucional de la República, es soterrado, el otro, el de la España franquista, acaba imponiéndose en el cierre de un documental dedicado, no lo olvidemos, a la extracción del aceite de oliva. Viene esto a demostrar cómo, aún en los años sesenta, las películas del Marqués de Villa-Alcázar siguen buscando pretextos para potenciar la exaltación franquista, en este caso a partir del borrado, mediante el uso de la metonimia, del período republicano anterior.

Luego de una parte del documental dedicada a la recogida de la aceituna y a los distintos métodos de extracción del aceite, segmentos posteriores se ocupan del filtrado, embotellado y precintado del aceite, antes de que de nuevo una suerte de epílogo, en este caso centrado en algunas de las aplicaciones de ese oro líquido marcado por sus calidades, ponga punto final al filme. Se estructura este epílogo en torno a una voz over que narra como sigue el episodio, limitándose las imágenes a una mera ilustración de lo dictado por la voz:

Salsa mahonesa... itan fácil de hacer hoy!: aceite de oliva, un huevo y condimentos. Medio minuto de motor en marcha, más aceite... Solo falta sacarla del vaso, cosa fácil, pero ¡cuidado!, algún diablillo puede venir a curiosear y... la encuentra excelente.

Gracias a esa salsa hay ensaladillas y gracias al aceite de oliva podemos disfrutar de la sabrosa y clásica tortilla de patatas que hoy ocupa lugar preferente entre los aperitivos...

También los popularísimos churros, conocidos en toda España, saboreados por los mayores y por los pequeñuelos, que a veces usan las dos manos.

Las señoras emplean aceite en varios productos de perfumería, y el clásico candil con su tenue luz alumbra aún faenas del hogar en algunas casas de labor.

La lamparilla de aceite da luz a una imagen religiosa en muchos hogares...

Y el aceite de oliva es el aceite litúrgico. Es que el que alimenta la llamita que día y noche ilumina el Sagrario, el que acompaña a nuestras oraciones, el que recibimos en el bautismo, el que nos acerca a Dios.

Interesante texto este sobre cuya génesis y expresión arroja luz su confrontación con el recogido en el guión literario original, que dice así:

¿Qué sería de las amas de casa sin el recurso de la salsa mahonesa, tan fácil de hacer hoy día?

Una taza de aceite de oliva a la que se le quitan cinco cucharadas, que se vierten sobre un huevo y los condimentos. Se pone en marcha el motor muy fácilmente y se deja en marcha medio minuto.

El resto del aceite se echa en forma de chorrito y eso es todo. Solo hace falta sacarla del vaso, cosa fácil, pero ojo, algún diablillo puede venir a curiosear y... al parecer la encuentra excelente.

Gracias a esa salsa hay ensaladillas y se pueden aliñar esos mejillones porque hay aceite.

¿Y qué sería de los churros sino existiera el aceite? Sencillamente, no habría churros y sería una lástima, porque la gente menuda bien disfruta comiéndolos, a dos manos.

Las señoras usan aceite en muchos productos de perfumería y de chiquitinas les da gran deleite que les froten la espalda con aceite.

Bien está disfrutando la fricción esta pequeñuela de veinte días. 
Pero, sobre todo, el aceite de oliva es el aceite litúrgico. Es que el que alimenta la llamita que día y noche ilumina el Sagrario, el que acompaña a nuestras oraciones, el que nos acerca a Dios. ${ }^{18}$

Constatamos, pues, cómo la película introduce notables modificaciones en relación a este texto primero del guión. Así, por lo que se refiere a la mahonesa, en el documental se elimina el "¿qué sería de las amas de casa...?”, quizá por lo hiperbólico del interrogante, y se resume en parte la explicación sobre la elaboración de esta salsa de la que, una vez cocinada, se destaca su sabor, mediante las imágenes de dos pequeñuelos metiendo en ella sus dedos antes de llevárselos a la boca, y su color, en este caso a través de su presentación como plato de ensaladilla, en una imagen de acusado cromatismo. De igual modo, se sustituye el episodio de los mejillones por el de la tortilla de patatas, plato este de ámbito más nacional y mucho más popular que aquel, y del que, además de su elaboración en la cocina de la casa, vemos su degustación por unas cuantas jóvenes reunidas en el salón familiar. Por lo que se refiere al episodio de los churros, el mismo se mantiene, pero eliminando igualmente el "¿qué sería de...", como en el caso de las mujeres. Asimismo, se reemplaza el segmento de la chiquitina a quien se frota la espalda desnuda, por los episodios del candil alumbrando a la mujer-madre en sus labores familiares - zurcir ropa en este caso-, primero, y de la lamparilla iluminando una imagen religiosa de la Virgen del Carmen, después. Y como cierre, se mantiene el episodio del Sagrario, de esa llamita que lo alumbra alimentada por un aceite del que se añade, además, que es el mismo que recibimos en el bautismo, en un segmento protagonizado por una joven que, prosternada en el reclinatorio, ora.

Es este que acabamos de describir un segmento ciertamente llamativo - sobre todo si tenemos en cuenta que forma parte de un documental dedicado a la extracción del aceite de oliva- que, tal como venía sucediendo desde los años cuarenta, demuestra el interés de la película por introducir en su final el toque o apunte religioso; toque que por lo demás se ve extraordinariamente potenciado, como acabamos de ver, con la transformación del guión literario en imágenes cinematográficas, al añadir estas una pequeña talla de la virgen del Carmen y aludir el narrador al aceite bautismal. Pero de esto nos ocuparemos más adelante, pues interesa comenzar apuntando las razones a las que atiende la incorporación de este toque religioso en Oro líquido por cuanto, como se desprende de la documentación de archivo encontrada, son exactamente las mismas que prevalecían en Trigo en España por mucho que, como antes señalábamos, hayan transcurrido más de veinte años entre un filme y otro. Vayamos, pues, con este tema. El 7 de septiembre de 1964, el Marqués de VillaAlcázar escribe una carta a la atención de monseñor Lamas, el censor religioso, en los siguientes términos:

Estamos preparando una película sobre la extracción del aceite de oliva [...] Teníamos pensado, para el final de la película, poner una serie de aplicaciones del aceite citado, todas, naturalmente, dentro de la seriedad que corresponde a un documento oficial como es una película del Ministerio de Agricultura, y como hemos hecho en varias películas, acabar con un tema religioso. Mucho le agradeceré dos letras de aprobación o de censura, para que pueda terminar mi trabajo ${ }^{19}$.

18 Archivo General de la Administración. Carpeta 36/04879. Exp. 257-64.

19 Archivo General de la Administración. Carpeta 36/04879. Exp. 257-64. 
En documento aparte, se detalla lo planeado, tal cual aparecía en el guión literario, pero especificando también ahora la banda imagen que acompaña la voz over del narrador:

Imagen:

Capilla del Sagrario, en primer término una lámpara de aceite, cristal rojo, al fondo el Sagrario. La cámara gira lentamente y encuadra una muchachita con mantilla rezando en un reclinatorio.

Locutor:

Pero, sobre todo, el aceite de oliva es el aceite litúrgico. Es el que alimenta la llamita que día y noche ilumina el Sagrario, el que acompaña nuestras oraciones, es el aceite que nos acerca a Dios ${ }^{20}$.

Todo ello hecho dentro del mayor respeto. La muchachita no es una actriz, es hija de familia profundamente católica. Dos hermanas de su madre son monjas del Sagrado Corazón de Caballero de Gracia (Álvarez de Toledo).

La brevísima alusión a los Santos Óleos está puesta en esa forma para quitarle lo lúgubre, pero dejando el fondo.

Como llevo hechas muchas películas (todas culturales, unos 125 títulos), tengo por costumbre no hacer nada que tenga el menor asomo de asunto religioso sin tener antes la aprobación de la Censura $^{21}$.

Al igual que Trigo en España, el Marqués de Villa-Alcázar pretende conseguir así que la censura religiosa dé el visto bueno al filme antes de que este haya sido rodado. Y lo hace, como en aquella ocasión, mediante una carta al censor religioso en la que especifica sin ambages el asunto del que se solicita opinión personal: el Sagrario, allí donde el aceite alimenta la llamita que alumbra el Santísimo y donde una mujer joven que no actúa - una mujer que no es actriz, sino la hija de una familia profundamente católica, se detalla en el escrito-, ora prosternada en un reclinatorio. Obsérvese hasta qué punto el texto anterior del Marqués de Villa-Alcázar quiere matizar así que no hay aquí fingimiento, sino verdad, que el narrador fundamenta en la ascendencia ilustre de la joven que reza. Doce días después de escribir la carta, concretamente el 19 de septiembre de 1964, el Marqués de Villa-Alcázar recibe la respuesta de monseñor Lamas, quien, entre otras cosas, dice:

Nada encuentro censurable desde el punto de vista religioso; pero le advierto que yo no soy el encargado de la censura cinematográfica para lo cual hay aquí equipos especiales. Ello no quiere decir que V. deba acudir a ellos, porque les corresponde ver las películas ya hechas y espero que nada encontrarán censurable en las palabras que V. copia en su nota ${ }^{22}$.

20 Archivo General de la Administración. Carpeta 36/04879. Exp. 257-64.

21 Ibídem

22 Ibídem 
Nada encuentra en efecto censurable Ramón Lamas en lo planificado por el Marqués de Villa-Alcázar, si bien advierte de que ello no es óbice para que acabada la película, esta hubiera de someterse, como era preceptivo, al dictado de los censores encargados de dar el visto bueno definitivo, por mucho que fuera de prever que nada iban a encontrar censurable. No conforme en todo caso con la respuesta, el Marqués de Villa-Alcázar vuelve a la carga seis días después de recibir esta comunicación, dirigiendo entonces una carta a su amigo Pinilla, en los siguientes términos:

Ya le indiqué de palabra mis deseos de no seguir adelante en el toque religioso que espero poner en
la película ORO LÍQUIDO, sobre extracción de aceite de oliva, sin tener la aprobación previa de la
censura eclesiástica. Con ese fin escribí el 7 de septiembre la carta que incluyo [...] y su respuesta
por parte de Monseñor Ramón Lamas [...] Como la mía del día 7 iba realmente dirigida a la
atención del Sr. Censor Religioso, creo lo más sencillo si la hace Vd. llegar a manos del Sr. Censor
Religioso de Cinematografía, con objeto de evitar correcciones en la película después de terminada,
las cuales son costosas y engorrosas ${ }^{23}$.

Obsérvese hasta qué punto el Marqués de Villa-Alcázar, por estar sumido en el mismo mar de dudas que ya padeció con su película Trigo en España, realizada más de veinte años antes, perseveraba para obtener, antes del rodaje del filme, el compromiso de aceptación por parte de la censura del asunto religioso a expresar. En el expediente de censura de la película no aparece la respuesta a esta última carta, pero cabe suponer que el Marqués de Villa-Alcázar obtuvo ese añorado visto bueno, dado que finalmente no sólo no eliminó el episodio, sino que, como hemos comentado más arriba, añadió otro previo igualmente amparado en la fe católica: ese en el que una lamparilla de aceite ilumina en el hogar familiar la imagen religiosa de la Virgen del Carmen. Resultaba así definitivamente formalizado un apunte religioso que por lo demás encontraba el motivo de su inclusión final en el filme en la aplicación del aceite de oliva como aceite litúrgico, no como aceite comestible, tal cual advertía la voice over del narrador en el arranque del epílogo; epílogo que, como hemos visto, pasa por destacar el uso del aceite en la elaboración de la salsa mahonesa y su empleo en la ensaladilla; en el cocinado de la popular de la tortilla de patatas, manjar típicamente español; en la freiduría de churros, delicia de mayores y pequeños; en los productos de perfumería de la mujer; en el candil que alumbra el hogar en las casas de labor; en las lamparillas de aceite que alumbran las imágenes religiosas en el hogar; y en el sostén de la llamita del Sagrario.

El aceite, pues, como alimento nutritivo humano, como cosmético y como fuente de luz del hogar familiar en su doble faceta, laica - alumbrando a la mujer en sus tareas familiares ${ }^{24}$ - y religiosa - alumbrando a la virgen, ejemplo de mujer-madre para todos los católicos ${ }^{25}$-, pero también, en lo que es la culminación del toque religioso final, como luz del Sagrario, lugar de oración y adoración a Dios. Tal es la

\section{Ibídem}

24 Aunque sea muy de pasada, el filme quiere aludir así al papel de la mujer dentro del hogar, de su trabajo en él como esposa y como madre. Para una mayor profundización en este tema, consúltese: Delgado, R. La mujer en la vida moderna. Madrid: Editorial Bruno del Amo (1941).

25 He aquí el porqué se optó por el aceite como luz del hogar, en su doble vertiente familiar y religiosa, en detrimento del aceite como deleite para la chiquitina a quien se frota la espalda, tal cual aparecía en el guión literario original. 
escritura cinematográfica de un toque religioso que quiere dar así buena cuenta de cómo la moral predicada por el nacional-catolicismo franquista imponía la obligación de obedecer las leyes y preceptos que preconizaba el credo religioso. De ahí que los ciudadanos - en este caso, representados por la mujer que reza- debían cumplir con plena fidelidad las normas establecidas por la Iglesia católica, que desarrolló así un fuerte dirigismo ideológico. Y es que, como apunta Ascunce, la religiosidad debía regir las prácticas personales y sociales de todos los buenos cristianos y de todos los buenos españoles ${ }^{26}$, cual es el caso de esa joven de familia profundamente católica, como tuvo buen cuidado en matizar el mismo Marqués de Villa-Alcázar en su carta a monseñor Lamas. Es así cómo, pese a lo avanzado del periodo franquista — estamos ya en el año 1964-, la fe católica continuaba siendo considerada, al igual que en los años cuarenta, elemento primordial de los documentales marquesianos, tal era su fuerte sintonía con el nacionalcatolicismo preconizado por el régimen.

\section{Dátiles y palmas: la palma blanca y la procesión de Ramos}

Pero entre Trigo en España y Oro líquido, otras películas marquesianas introducen igualmente un segmento religioso en su final: es el caso, por ejemplo, de Dátiles y palmas (1947) allí donde la voice over del narrador calla para dar paso a las imágenes de la procesión de Ramos introducidas con el pretexto de hacer ver una de las aplicaciones dadas a la palma blanca obtenida de las palmeras españolas. Ya los títulos de crédito del filme incorporan motivos pictóricos referidos a la palmera en sus vertientes californiana y española, aquella como productora de dátiles y esta de palmas, palmas que enarbolan unos niños que acuden a la procesión del Domingo de Ramos. Estructuralmente, el documental se divide en cuatro partes, a saber, las palmeras californianas, las palmeras españolas, el trabajo con las palmas y la parte final referida de la procesión de Ramos. Resulta especialmente interesante la parte tercera allí donde las imágenes se interesan por las habilísimas manos femeninas trenzando las palmas para transformarlas en llamativas figuras, así la Virgen de la Asunción o la Magrana del Misteri d'Elx, y motivos llenos de creatividad, como la cruz o la flor de Lis. Figuras y motivos pues, religiosos, todos ellos, alusivos tanto al Cristo (la cruz), cuanto a la Virgen María (la flor de lis como símbolo mariano), y más concretamente, a la Asunción (la Magrana del Misteri d'Elx es el aparato aéreo más característico del drama religioso asuncionista que recrea la Dormición, Asunción y Coronación de la Virgen). Pero al igual que en las películas anteriores del Marqués, junto a la religión asoma también el patriotismo, si bien en este caso de modo indirecto. Y ello porque aun cuando esta artesanía de la palma ha tenido siempre una gran tradición y asentamiento en Elche, el narrador alude a cómo la misma estuvo a punto de desaparecer "años atrás". Sin duda se trata de cargar así las culpas de ello sobre la República, tachada de este modo de insensible a una práctica finalmente recuperada, viene a decir el documental, por el franquismo. Pero si la religiosidad aparece ya aquí para vincularse al patriotismo, el apunte religioso más notable se escribe una vez más en el segmento que cierra el filme. 
Un segmento que comienza con el narrador anunciando: "Y una mañana, España despierta en Domingo de Ramos". La voz calla entonces para dar paso a las imágenes de la procesión de la borriquita, el pas de la burreta, donde un gentío numeroso arropa el trono en la celebración del Domingo de Ramos, que conmemora la entrada de Jesús en Jerusalén y marca el inicio de la Semana Santa. Decenas de miles de personas acompañan el paso de Jesús Triunfante por las calles de la ciudad enarbolando sus palmas - entre las que destacan las rizadas representando las figuras y motivos antes citados, como la Virgen de la Asunción, patrona de la ciudad, la Magrana del Misteri d'Elx, la cruz o la flor de lis - en exaltación de júbilo, en unas imágenes que no dejan de recordar, como ha señalado Julián Casanova, que la Semana Santa fue ya desde 1939, año de la victoria franquista, una extraordinaria ocasión para el nuevo régimen de restaurar en las ciudades españolas la liturgia de fechas tan señaladas:

El triunfo de la ciudad de Dios y la resurrección de España. Se iniciaba así una nueva liturgia barroca, político-religiosa, llena de gestos, creencias y fervor, con los Cristos saliendo de las iglesias en procesión y la multitud recibiéndole con saludos fascistas ${ }^{27}$.

Otra vez aunando religiosidad y patriotismo, Dátiles y palmas se alía definitivamente con la ideología del nacionalcatolicismo preconizada por el régimen franquista, y lo hace, como es frecuente en los documentales del Marqués de VillaAlcázar, a propósito de una temática colateral, cual es el uso en este caso de la palma blanca. En efecto, ello es el motivo del segmento último del filme dedicado en su totalidad a una celebración religiosa, la procesión de La Borriquita del Domingo de Ramos, y dar cuenta así del fervor religioso del pueblo español luciendo sus mejores galas y acompañando el paso con un mosaico de palmas artesanales como señal de júbilo, respeto y devoción.

\section{A modo de coda}

Las películas agropecuarias del Marqués de Villa-Alcázar suponen un hito en la todavía poco estudiada historia del documental rural en España, y ello por la notable carga ideológica de la que son portadoras; carga que, prácticamente ausente en el resto de la producción documental agraria de los años del franquismo, puede emanar de la parábola de la que a veces se ayudaba como recurso didáctico la cinta marquesiana, o puede, también, anidar en el llamado "toque" religioso — en palabras del mismo Marqués - movilizado por el filme. El presente trabajo se ha ocupado de este último caso, habiendo podido constatar cómo tales documentales del Marqués se estructuran en su final en torno a un apunte espiritual o religioso - así sea la transubstanciación del pan en el cuerpo de Cristo, la presencia de una mujer ante el Altísimo iluminado por una llama que sobrenada en aceite, o la procesión de palmas del Domingo de Ramos- que, apoyándose en determinados motivos relacionados con el tema agropecuario tratado por el filme - el trigo, el aceite o la palmera-, es acorde con dos de los valores predicados por el catecismo franquista: catolicidad

27 Casanova, J. "La dictadura que salió de la guerra", en Julián Casanova (ed.): 40 años con Franco, Crítica: Barcelona (2015: 55). 
y españolidad. El estudio de este apunte, cuyo trazado en la escritura del guión era ya sometido al arbitrio personal de los censores eclesiásticos, da buena cuenta del temor del Marqués de Villa-Alcázar a una posible modificación del mismo cuando, con vistas a su implantación en el filme correspondiente, era transformado en formas cinematográficas. Y ello por mucho que con este apunte o toque religioso no se buscara sino la exaltación de un régimen - en concreto del ritmo ideológico del pensamiento franquista - que ponía así de manifiesto su celo en el tratamiento - en este caso cinematográfico - de asuntos religiosos. Sea como sea, el hecho es que, junto al didactismo sobre el campo y sus productos, estos documentales son también reflejo de una época de la historia de España fuertemente condicionada y aleccionada por el franquismo.

\section{Bibliografía}

Ascunce, J. A. (2015). Sociología cultural del franquismo (1936-1975). La cultura del nacional-catolicismo. Madrid: Biblioteca Nueva.

Botti, A. (1992). Cielo y dinero. El nacionalcatolicismo en España (1881-1975). Madrid: Alianza Editorial.

Camarero, F. (2014). Catálogo de Documentales Cinematográficos Agrarios 1895-1981. Madrid: Magrama.

Casanova, J. (ed.) (2015). 40 años con Franco. Barcelona: Crítica.

Delgado, R. (1941). La mujer en la vida moderna. Madrid: Editorial Bruno del Amo.

Gómez-Tarín, F. J.; Parejo, N. (coords.). (2013). Discursos y narraciones en el documental rural: el marqués de Villa-Alcázar. Tenerife: Universidad de La Laguna.

Gubern, R. (1981). La censura. Función política y ordenamiento jurídico bajo el franquismo (1936-1975). Barcelona: Península.

Miralles, A. (1933). "El cinema en la agricultura", $A B C, 31$ de marzo de 1933, Madrid.

VV.AA. (1944). Conferencias pronunciadas en la emisión Radio Agrícola. Madrid: Ministerio de Agricultura. 